\title{
The evolving domain of entrepreneurship research
}

\author{
Bo Carlsson • Pontus Braunerhjelm • \\ Maureen McKelvey • Christer Olofsson • \\ Lars Persson · Håkan Ylinenpää
}

Accepted: 5 September 2013/Published online: 21 September 2013

(C) The Author(s) 2013. This article is published with open access at Springerlink.com

\begin{abstract}
Research on entrepreneurship has flourished in recent years and is evolving rapidly. This article explores the history of entrepreneurship research, how the research domain has evolved, and its current status as an academic field. The need to concretize these issues stems partly from a general interest in defining the current research domain and partly from the more specific tasks confronting the prize committee of the Global Award for Entrepreneurship Research. Entrepreneurship has developed in many sub-fields within several disciplines_-primarily
\end{abstract}

B. Carlsson ( $\square)$

Case Western Reserve University, Cleveland, OH, USA

e-mail: Bo.Carlsson@case.edu

P. Braunerhjelm

Royal Institute of Technology, Stockholm, Sweden e-mail: Pontus.Braunerhjelm@entreprenorskapsforum.se

M. McKelvey

Gothenburg University, Göteborg, Sweden

e-mail: Maureen.McKelvey@handels.gu.se

C. Olofsson

University of Agriculture, Uppsala, Sweden

e-mail: Christer.Olofsson@ekon.slu.se

\section{Persson}

Institute of Industrial Economics, Stockholm, Sweden

e-mail: Lars.Persson@ifn.se

H. Ylinenpää

Luleå University of Technology, Luleå, Sweden

e-mail: Hakan.Ylinenpaa@ltu.se economics, management/business administration, sociology, psychology, economic and cultural anthropology, business history, strategy, marketing, finance, and geography-representing a variety of research traditions, perspectives, and methods. We present an analytical framework that organizes our thinking about the domain of entrepreneurship research by specifying elements, levels of analysis, and the process/context. An overview is provided of where the field stands today and how it is positioned relative to the existing disciplines and new research fields upon which it draws. Areas needed for future progress are highlighted, particularly the need for a rigorous dynamic theory of entrepreneurship that relates entrepreneurial activity to economic growth and human welfare. Moreover, applied work based on more careful design as well as on theoretical models yielding more credible and robust estimates seems also highly warranted.

Keywords Entrepreneurship research .

Evolution - Academic disciplines - Global Award for Entrepreneurship Research

JEL Classifications L26

\section{Introduction}

It is now generally recognized that entrepreneurial activity is one of the primary drivers of industrial dynamism, economic development, and growth. Yet 
research on entrepreneurship is relatively recent and rapidly evolving. Entrepreneurship has developed in many sub-fields within several disciplines-primarily economics, management/business administration, sociology, psychology, economic and cultural anthropology, business history, strategy, marketing, finance, and geography-representing a variety of research traditions, perspectives, and methods.

In order to highlight this new research area, the Global Award for Entrepreneurship Research was initiated in 1996; it has since evolved into the most prestigious prize in this vein of research. ${ }^{1}$ The prize is given annually to a scholar who has produced "scientific work of outstanding quality and importance, thereby giving a significant contribution to theorybuilding concerning entrepreneurship and small business development, the role and importance of new firm formation and the role of SMEs in economic development." The background to and organizations behind the award, and the criteria used in the selection process, are presented in Henrekson and Lundström (2009) and Braunerhjelm and Henrekson (2009).

From the point of view of the Prize Committee that selects the winner of the Award, it is useful and perhaps even necessary to ask, what is the domain in which we want to stimulate research? What are the areas of inquiry and types of research we want to promote in this rapidly evolving field of research? And how is this domain positioned relative to existing disciplines on which it draws? These questions all contribute to an understanding of how to define and understand the domain of entrepreneurship research. This article is written jointly by the members of the prize committee serving in 2011-2012.

\footnotetext{
${ }^{1}$ The Global Award is a direct continuation of the International Award for Entrepreneurship and Small Business Research first launched in 1996 by The Swedish Entrepreneurship Forum (then the Foundation for Small Business Research, FSF) and the Swedish Agency for Economic and Regional Growth. Since 2009, these two organizations have been joined by The Research Institute of Industrial Economics (IFN) thanks to a generous donation by the Swedish industrialist Rune Andersson, Mellby Gård AB, for the period 2009-2012. Regarding the coming years, another Swedish industrialist and entrepreneur, Melker Schörling, has contributed a similarly generous donation to the Swedish Entrepreneurship Forum, which is matched by a grant of the same magnitude from the Swedish Governmental Agency for Innovation Systems (Vinnova), which will secure funding of the Prize until 2016. The prize consists of 100,000 euros and a statuette, the "Hand of God," by the internationally renowned sculptor Carl Milles.
}

In order to define the domain of entrepreneurship research, an historical understanding of the main debates and contributions is needed. First, however, we present the results of our work, namely an analytical framework and definition of the field. The reason for presenting these first is that the framework provides a useful tool to understand the specific elements, levels of analysis as well as processes/ contexts of entrepreneurship research and how they are related. From there, we move on to a review of how the field has evolved over time, including modern influential work as represented by the contributions of the winners of the Global Award for Entrepreneurship Research. The article concludes with a discussion of how the field is evolving, where the gaps are in our current knowledge, and what seem to be promising areas for future research.

\section{The domain of entrepreneurship research}

\subsection{Definition of the domain}

We define the domain of entrepreneurship research as follows:

Entrepreneurship refers primarily to an economic function that is carried out by individuals, entrepreneurs, acting independently or within organizations, to perceive and create new opportunities and to introduce their ideas into the market, under uncertainty, by making decisions about location, product design, resource use, institutions, and reward systems. The entrepreneurial activity and the entrepreneurial ventures are influenced by the socioeconomic environment and result ultimately in economic growth and human welfare.

The domain of entrepreneurship research embraces numerous dimensions, and the analysis can be carried out at various levels (individual or team level, venture and firm level, and macroeconomic level). The socioeconomic environment, consisting of institutions, norms, and culture as well as availability of finance, knowledge creation in the surrounding society, economic and social policies, the presence of industry clusters, and geographic parameters, may influence entrepreneurial activities at all levels.

The explorative side of entrepreneurship consists of the role and characteristics of individuals and teams (organizations). The result of these activities is 
opportunity recognition, innovation and venture creation. Venture creation can take the form of creation of new organizations or of new activities in existing organizations. The aggregate outcomes take the form of economic growth/development and human welfare. All the activities and outcomes are influenced by one or more dimensions of the socioeconomic environment.

Explorative entrepreneurial activities lead to the creation of new firms and new activities in existing organizations, shifting the focus from the characteristics and behavior of the entrepreneur to the function of entrepreneurship. As pointed out by Venkataraman (1997),

[e]conomists do not define economics by defining the resource allocator, nor do sociologists define their subject matter by defining society. Likewise, it would be a mistake for us to define our field by defining the entrepreneur. It would be more useful to define the field in terms of the central issues that concern us... Our field is fundamentally concerned with understanding how, in the absence of current markets for future goods and services, these goods and services manage to come into existence. Thus, entrepreneurship as a scholarly field seeks to understand how opportunities to bring into existence 'future' goods and services are discovered, created, and exploited, by whom, and with what consequences... At its core the field is concerned with (1) why, when and how opportunities for the creation of goods and services in the future arise in an economy; (2) why, when, and how some are able to discover and exploit these opportunities, while others cannot or do not, and, finally, (3) what are the economic, psychological, and social consequences of this pursuit of a future market not only for the pursuer, but also for the other stakeholders and for society as a whole. (Venkataraman 1997, pp. 120-121)

The fact that entrepreneurial activities are viewed from multiple disciplinary perspectives and at various levels of analysis, using a variety of methods, makes it difficult to define the boundaries of the domain. Besides economics, there is a growing body of research in politics, sociology, psychology, economic anthropology, business history, management, strategy, marketing and finance, as well as geography (Casson
1982; Acs and Audretsch 2003a, b). Thus, entrepreneurship can be seen as a subfield within several disciplines, each with its own perspective on the subject matter. One result, pointed out by many authors, is a lack of a common theoretical framework or central research paradigm.

Although many subfields work within their subparadigms, our view is that entrepreneurship research may also be viewed as a system that interacts with other parts of the economic system as a whole. Research on entrepreneurship can also be understood as a complex system where each separate level of analysis and each component can be seen to contribute to a broader understanding of the phenomena.

\subsection{Definitions of "entrepreneur" and "entrepreneurship"}

There are many definitions of "entrepreneur" and "entrepreneurship." Casson (1982) defined an entrepreneur as someone who specializes in making judgmental decisions about the coordination (not just allocation) of scarce resources, emphasizing that "judgmental decisions" implies decision-making under uncertainty and that the ability to identify and exploit opportunities is essential.

Hébert and Link (1989, p. 47) defined the entrepreneur quite similarly: "The entrepreneur is someone who specializes in taking responsibility for and making judgmental decisions that affect the location, the form, and the use of goods, resources, or institutions." They call this definition 'synthetic' because it incorporates the main historical themes of entrepreneurship: risk, uncertainty, innovation, perception, and change. It accommodates a range of entrepreneurial activities within a market system, including, but not limited to, coordination, arbitrage, ownership, speculation, innovation, and resource allocation (Hébert and Link 1989, p. 47).

Shane and Venkataraman (2000) adopted a definition very similar to that of Venkataraman (1997, cited above), while Acs and Audretsch (2003a, b, p. 6) defined entrepreneurship as embracing "all businesses that are new and dynamic, regardless of size or line of business, while excluding businesses that are neither new nor dynamic as well as all non-business organizations." This leaves the entrepreneurial process, opportunity, and the nature of organizational interaction as core topics. 
Stevenson (2004, p. 3) defined entrepreneurship more narrowly (on the 'exploration' rather than 'exploitation' side of the domain) as "the pursuit of opportunity beyond the resources you currently control." He identifies six different dimensions of entrepreneurship: strategic orientation, commitment to opportunity, commitment process, control of resources, management structure, and compensation and reward system.

In 1998, the OECD published a report entitled Fostering Entrepreneurship, defining entrepreneurship in more exploitative terms and closer to outcomes at the aggregate level as follows:

Entrepreneurship is central to the functioning of market economies. Entrepreneurs are agents of change and growth in a market economy and they can act to accelerate the generation, dissemination and application of innovative ideas. In doing so, they not only ensure that efficient use is made of resources, but also expand the boundaries of economic activity. Entrepreneurs not only seek out and identify potentially profitable economic opportunities but are also willing to take risks to see if their hunches are right. While not all entrepreneurs succeed, a country with a lot of entrepreneurial activity is likely to be constantly generating new or improved products and services. (OECD 1998, p. 12)

\section{Historical overview}

\subsection{Origins of the field}

Entrepreneurship research is relatively new as an academic field, but it has a long tradition (Landström 1999, 2000, 2005). The term "entrepreneur" has been used in the French language since the twelfth century, but the feudal system dominating in Europe in the Middle Ages hampered the development of entrepreneurship and innovation. Gradually emerging cities became a breeding ground for entrepreneurship among the merchant class, especially in Italy, France, and Southern Germany. By the eighteenth century feudalism was eliminated, and legal and institutional conditions had changed with the emergence of the joint stock company and the development of a banking system (Wennekers and Thurik 1999, 2001).
It was the writings of the Irish-born banker Richard Cantillon (circa 1680-1734), whose Essai Sur la Nature du Commerce en Général (Cantillon 1755) was published posthumously, that gave the concept of entrepreneurship an economic meaning and the entrepreneur a role in economic development (Cornelius et al. 2006). Cantillon defined discrepancies between supply and demand as options for buying cheaply and selling at a higher price. He referred to persons who were alert to such options as 'entrepreneurs.' He identified their role as purchasing inputs at a certain price and selling outputs at an uncertain price, bringing a market system toward stability. This set the stage for the later development of equilibrium models in classical economics by promoting the development of economic foresight and dealing with uncertainty (Murphy et al. 2006, pp. 18-19). But for a long time, "classical" economic theory, originating in Adam Smith's Inquiry into the Nature and Causes of the Wealth of Nations (1776/1976), dominated the intellectual development of economics. Classical theory did not emphasize the entrepreneurial function in the economy. Among the early economists only a few, such as Jean-Baptiste Say (1767-1832), Jeremy Bentham (1748-1832), and John Stuart Mill (1806-1873), mentioned the concept. With the rise of the United States as a major industrial power at the end of the nineteenth century, the discussion on entrepreneurship shifted across the Atlantic. Among the American economists who developed the discussion were Francis Walker, Fredrick Hawley, and John Bates Clark. Perhaps the best-known author among the US economists was Frank Knight (1885-1972), who in his Risk, Uncertainty and Profit (1921) made a distinction between risk and uncertainty, where uncertainty is unique and uninsurable, and argued that the skills of the entrepreneur lie in the ability to handle the uncertainty that exists in any given society.

The first economist to focus on the role of entrepreneurship in economic development was Joseph A. Schumpeter (1885-1950). In his seminal work Theorie der Wirtschaftlichen Entwicklung [1912, the second edition of which was translated and published as The Theory of Economic Development (Schumpeter 1934)], Schumpeter tried to develop an entirely new economic theory based on change-as opposed to equilibrium. Distinguishing between 'economic growth' in the stationary state and 'economic development' (the creation of new 
opportunities through 'creative destruction'), he discussed the function of the entrepreneur as an individual who tends to break the equilibrium by introducing innovations ("new combinations") into the system. He argued that "creative destruction is the essential fact about capitalism" (Schumpeter 1942, p. 83) and that the entrepreneur is the prime agent of economic change. This ability to break with established practice was linked primarily to individual entrepreneurs. Schumpeter saw new combinations as fundamental for economic development. But later as he observed the increasing dominance of large corporations in industrial society, Schumpeter's view of entrepreneurship gradually changed-from entrepreneurship as the achievement of a single individual to innovative activities in existing organizations (Schumpeter 1942).

\subsection{Early postwar period}

World War II clearly changed the political, technological, and economic environment. The United States was catapulted into a position of leadership in technology, production, management, and institutions. The war-related products (such as computers, jet engines, and radar) that emerged from the war were commercialized almost immediately through the military and soon after converted into civilian products. But the commercialization took place mainly through incumbent firms; few new firms were created. Entrepreneurial activity in the form of new firm formation declined or stagnated between 1950 and 1965 and remained at a low level until around 1980 (Carlsson et al. 2009).

Given these circumstances, it is understandable that there was not much progress in entrepreneurship research during this period. But as is often the case, practice went ahead of theory; entrepreneurship entered the study of management before it penetrated into economic analysis. The first course in entrepreneurship was offered at the Harvard Business School in 1947. Peter Drucker started a course in entrepreneurship and innovation at New York University in 1953. The first conference on small businesses and their problems was held at the University of St. Gallen in Switzerland in 1948. The National Council for Small Business Management Development (re-named the International Council for Small Business, ICSB, in 1977) held its first conference in 1956. The first academic conference on entrepreneurship research took place at Purdue University in 1970. The Entrepreneurship Division of the Academy of Management was established in 1987; it grew out of an Interest Group on Entrepreneurship formed in 1974. The Babson Research Conference was started in 1981 (Cooper 2003, pp. 21-22). Hence, there was much interest in entrepreneurship in practice, even if not a central idea in economic theory.

Meanwhile, the study of entrepreneurship developed along two tracks, both based on the work of Austrian economists: Schumpeter $(1934,1942)$ on the one hand and Hayek (1945) and von Mises (1949) on the other. While it took a few more years for Schumpeter's work to be incorporated in economic analysis, Kirzner (1973, 1979, 1985), drawing on Mises and Hayek, focused on the role of knowledge and entrepreneurial discovery in the process of market equilibration. Moreover, Kihlstrom and Laffont (1979) constructed a theory of competitive equilibrium under uncertainty, using an entrepreneurial model with roots in the work of Knight (1921). The Austrian economists have thus influenced many later works.

In the last decade of his life, Schumpeter called repeatedly for empirical historical studies of entrepreneurship (Courvisanos and Mackenzie 2011). It is not surprising, therefore, that his ideas on the entrepreneurial role in economic development and business cycles penetrated first into the study of economic history. With Schumpeter's endorsement and help in securing funding, the Committee on Research in Economic History was created in 1940, funded by the Social Science Research Council and headed by Arthur Cole, an economic history professor and colleague of Schumpeter at Harvard. ${ }^{2}$ The Committee selected two major fields for special inquiry, namely the role of government and the role of entrepreneurship in American economic development (Cole 1944). By 1948 Cole had established Harvard's Research Center in Entrepreneurial History and its journal Explorations in Entrepreneurial History.

To Cole it was transparently obvious that the entrepreneurial role had now to be built into

\footnotetext{
2 Although Schumpeter was not a member of the Committee, Cole (1970, p. 733) acknowledged him as "the real innovator" and thanked him for giving his blessing.
} 
economic theory, if economists were ever going to become "realistic" in their studies of the economic world. For without the entrepreneur, nothing happens in economic life. Factors of production do not magically spring into combination to make economic enterprises. The entrepreneur accomplishes this economic service. The existing theories of the firm and of markets were thus incomplete. Economics was said to be a social science, and therefore it must embrace the central figure in economic society, the person whose actions create all economic change. Economics would no longer be merely a study of an abstract world without people, institutions, technological change, or the passage of time. The study of entrepreneurial history would lead the way. (Hughes 1983; italics in the original)

However, this proved to be a false start of economic analysis of entrepreneurship; already by 1958 the Center had closed its doors. As predicted by Schumpeter, technological change had shifted innovation from the individual entrepreneur to large firms. Business historians such as Chandler (1962, 1977, 1990) ${ }^{3}$ studied the history of large firms, while the focus of research in economic history in general shifted away from entrepreneurial history. The field of entrepreneurial history seemed to have come to a dead end. Twenty-five years later Hughes commented that "[a]ppallingly enough, the most recent excursions into the entrepreneurial regions by economists display no apparent knowledge of the earlier voyages launched from the Harvard center in the 1950s" (Hughes 1983, p. 134).

Thus, in spite of Schumpeter's contributions, it took a long time for the concept of the entrepreneur to be used in economic analysis. Traditional neoclassical economic analysis focused on equilibrium and ignored the role of entrepreneurial activity for the economy. It was left to behavioral scientists to continue theoretical development in entrepreneurship research. David McClelland (1917-1998), a psychologist, was one of the first to present empirical studies in the field of entrepreneurship that were based on behavioral science theory. McClelland was interested primarily in

\footnotetext{
${ }^{3}$ Chandler received his $\mathrm{PhD}$ in economic history at Harvard in 1952 and was associated with the Center.
}

human motivation. In his pioneering work The Achieving Society (1961), McClelland made an attempt to understand the reasons for economic growth and decline by focusing on the role of the entrepreneur. The question he raised was: Why are certain societies more dynamic than others?

For McClelland, the premise was that the norms and values that prevail in any given society, particularly with regard to the need for achievement $(\mathrm{nACH})$, are of vital importance for the development of that society. By means of a large number of experimentally constructed studies, McClelland showed the link between a country's $\mathrm{nACH}$ and its economic development. He concluded that countries that are economically more developed are characterized by a stronger focus on institutional norms and openness toward other people and their values, as well as communication between people. It is in this context that entrepreneurs have been recognized as an important driving force for development. Entrepreneurs are people who have a high nACH coupled with strong self-confidence and independent problem solving skills, and who prefer situations that are characterized by moderate risk, while accepting individual responsibility. (Cornelius et al. 2006, p. 381)

McClelland's work generated a stream of research by behavioral scientists on the role of entrepreneurship in economic development. Geertz, a cultural and social anthropologist, studied social development and economic change in Indonesia (Geertz 1963); Barth (1963), a social anthropologist, looked at the role of entrepreneurs in social change in Norway; Lipset, a political sociologist, examined values, education, and entrepreneurship in Latin America (Lipset 1967). As noted in the introduction to the first compilation of articles on entrepreneurship education and research (Kent et al. 1982), "the greatest abundance of research data lies in the psychology of entrepreneurship, sociology of entrepreneurship, and venture capital. Other important areas-innovation from entrepreneurship, the environment for entrepreneurship, and the technology of entrepreneurship (how to perform it well) - are lean on research" (Vesper 1982, p. xxxiii).

The behavioral approach to the study of entrepreneurship led to a body of research focusing on the 
'traits' of the individual entrepreneur. For a review of this literature, see Gartner (1988).

It was not until the late 1960s that economists began to take an interest in the role of entrepreneurship in economic development (Leibenstein 1968) and economic theory (Baumol 1968); both of these authors lamented the absence of the entrepreneurial function in conventional economic analysis. As Baumol (1968) pointed out, the reason why entrepreneurship research has made a slow entrance into economic analysis is that there is no theory of entrepreneurship in standard (neoclassical) economics. "[T]here is no room for enterprise or initiative. The management group becomes a passive calculator that reacts mechanically to changes imposed on it by...external developments over which it does not exert, and does not even attempt to exert, any influence" (p. 67). "The theoretical firm is entrepreneurless- the Prince of Denmark has been expunged from the discussion of Hamlet" (p. 66). The neoclassical model is essentially an instrument of optimality analysis; "maximization and minimization have constituted the foundation of our theory, [but] as a result of this very fact the theory is deprived of the ability to provide an analysis of entrepreneurship" ( $p$. 68).

Casson (1982) argues that one reason why there is no economic theory of the entrepreneur lies in the extreme assumptions about access to perfect information that are implicit in orthodox (neoclassical) economics. Simple neoclassical models typically assume that everyone has free access to all the information required for taking decisions. This is the view that Hayek (1945) challenged. This assumption reduces decision-making to the mechanical application of mathematical rules for optimization; it trivializes decision-making and makes it impossible to analyze the role of entrepreneurs in making judgmental decisions (Casson 1982, p. 9).

The need for a theory of the entrepreneur "is most apparent when analyzing the reasons for economic success and failure. The problem of explaining why some succeed while others fail is crucial to the study of economic development, the growth of the firm and the distribution of income" (Casson 1982, p. 10).

Schumpeter's analysis has remained a basic point of reference for many of his successors, especially for those who follow his tradition of regarding the entrepreneur as an innovative path breaker (e.g., Dahmén 1950; Leibenstein 1968; Baumol 1968,
1990). But it was not until Schumpeterian analysis made a comeback in the form of evolutionary economics and industrial economics became more dynamic based on a new theory of the firm and the emergence of game theory, breaking away from standard neoclassical economics, that the entrepreneur began to be incorporated in economic analysis. Among the early contributors were Klein (Dynamic Economics, 1977) and Nelson and Winter (An Evolutionary Theory of Economic Growth, 1982), who emphasized the importance of unpredictability, bounded rationality, and individualistic behavior in a dynamic economy. As Casson (1982) pointed out,

"The theory of the entrepreneur has an important role in the field of economic dynamics. Orthodox theory provides an unsatisfactory account of the way in which individuals and economic systems adjust to change. The neoclassical theory is inherently static in its approach, and is usually rendered dynamic simply by introducing ad hoc assumptions about adjustment lags. It offers very little insight into the ways in which different economic systems adjust to change. It trivializes the comparison of market economies and centrally planned economies by focusing on the case of perfect information in which resources are reallocated simply by applying two different version of the conditions for the same mathematical optimum." (Casson 1982, p. 12)

Entrepreneurial activity is closely linked to the Austrian view of individual actions and choice. Individuals do not behave like calculating robots that choose one strategy among known alternatives whose outcomes are known (probabilistically). The future is not only unknown but also unknowable; future outcomes are often impossible to predict. Such a view of choice and decision-making opens up space for innovativeness, boldness, and creativity, which have no room in traditional microeconomic decision theory (Henrekson and Stenkula 2007, p. 51).

\subsection{The 1980s and 1990s}

The year 1980 represents something of a turning point for both entrepreneurial activity and entrepreneurship research. A number of institutional reforms in the US (including strengthening of intellectual property rights, the enactment of the Bayh-Dole Act, changes 
in tax laws, and deregulation of financial institutions that created new financial instruments) mark a transition to a new technological regime in which new business formation plays an increasing role in converting new knowledge into economic growth. The breakthrough in DNA research and the microprocessor revolution also played a role (Carlsson et al. 2009). Entrepreneurial activity began to pick up as the dynamism of the economy increased. It became evident that large firms were not always superior in promoting technological development and economic growth. The "twin oil crises" in the 1970s triggered a re-appraisal of the role of small firms. Many large companies were hit by severe economic difficulties. Large companies were increasingly seen as inflexible and slow to adjust to new market conditions (Carlsson 1989a, b). The increased interest in smaller firms can be attributed to (1) a fundamental change in the world economy, related to the intensification of global competition, the resulting increase in the degree of uncertainty, and greater market fragmentation, and (2) changes in the characteristics of technological progress giving large firms less of an advantage (Carlsson 1992).

These changes in the economic environment were reflected in three broad waves that swept the subject of entrepreneurship forward: (1) an explosion of popular literature on the subject in new practitioner-oriented journals such as Entrepreneur, Venture, and Inc.; (2) an increase in course offerings in entrepreneurship; and (3) increasing US government interest in venture initiation (Vesper 1982).

The new trends are also reflected in numerous scholarly works concerning entrepreneurship and the role of small business. For example, in his pathbreaking report The Job Generation Process (1979), David Birch found that the majority of employment opportunities in the US were created by small and young firms-not large companies. In The Changing Structure of the US Economy: Lessons from the US Steel Industry (1984), Zoltan Acs argued that small firms had an innovative role in the economy as agents of change. Michael Piore and Charles Sabel, in The Second Industrial Divide (1984), conducted a macrohistorical analysis of the transformation from Fordist mass production to flexible specialization in Italian industrial districts. As a consequence, a large number of enthusiastic researchers with different backgrounds and different interests began to do research in this new area. The growth of the field of entrepreneurship research had begun.

As tends to be the case in a new field of research, new journals dedicated to the new field emerged. As indicated earlier, Explorations in Entrepreneurial History was started in 1949 and later re-named Explorations in Economic History. The Journal of Small Business Management was started in 1963 and the American Journal of Small Business in 1976 (renamed Entrepreneurship Theory and Practice in 1988). The new journals that emerged were the Journal of Business Venturing (1985), Family Business Review (1988), Small Business Economics (1989), Entrepreneurship and Regional Development (1989), and Small Business Strategy (1990). ${ }^{4}$ The number of English language entrepreneurship journals now exceeds 40 (Cooper 2003, pp. 22-24). The leading journals publishing work in entrepreneurship are not discipline-based. But it should be noted that entrepreneurship research is also published in discipline-based journals such as the American Economic Review, the American Sociological Review, Administrative Science Quarterly, the Journal of Financial Economics, and the Strategic Management Journal. ${ }^{5}$

The explosion in the number of entrepreneurshiporiented journals in the 1980s and 1990s reflects the similarly dramatic increase in entrepreneurial activity that took place at the same time (Gartner and Shane 1995; Carlsson et al. 2009). But the entrepreneurship field is still relatively small, particularly in terms of the number of full-time faculty doing research. And although there has been rapid growth in the total number of courses, many courses are taught by nontenure track faculty, often on a part-time basis (Cooper 2003, p. 24).

\footnotetext{
${ }^{4}$ It is interesting and illuminating that through the 1990s there was little distinction made between "small business" and "entrepreneurship."

${ }^{5}$ It is noteworthy that the economics discipline has been slow to accept the notion of entrepreneurship. Out of 1,285 articles published in Industrial and Corporate Change, the International Journal of Industrial Organization, the Journal of Evolutionary Economics, and Research Policy during the 1990 s, only $25(1.9 \%)$ had some form of the word "entrepreneur" in their abstracts compared to 53 of 316 articles (16.8\%) in Small Business Economics between 1992 and 1999. On the other hand, 71 of 378 articles in the International Journal of Industrial Organization 1990-1999 had the word "entry" in the abstract compared to 28 of 316 articles in Small Business Economics 1992-1999.
} 
Noting the lack of a common core or understanding of the field, Gartner (1990) conducted a Delphi study of academics, business leaders, and politicians in an attempt to define entrepreneurship. No common definition resulted, but eight themes emerged: the entrepreneur, innovation, organization creation, creating value, profit versus nonprofit, growth, uniqueness, and the owner-manager.

As shown above, most early scholarly work on entrepreneurship focused on the personal characteristics ("traits") as well as success or failure of individual entrepreneurs and firms, primarily as a consequence of the research being based in psychology and sociology. Organizational sociologists have focused on populations of firms in considering organizational births and deaths (Cooper 2003). ${ }^{6}$ When economists finally became engaged, the research focus broadened, but there was no agreement on the boundaries of the field.

As we have seen, the stream of research on individuals and teams is strongly rooted in behavioral science and focuses on the 'intrapersonal' processes of individual entrepreneurs. These include social cognition, attribution, attitudes, and the self. The processes of social cognition that have received the most attention within entrepreneurship are the cognitive biases and heuristics, and the principles of attribution. In the social psychology literature, 'attribution' refers to the cognitive processes by which people explain their own behavior, the actions of others, and events in the world. The work that provided the foundation for attribution theory is by Heider (1958) who argued that behavior is a function of both the person and external environment (Shaver 2003, pp. 331-336).

As mentioned before, the earliest reference to studies of entrepreneurial behavior was by the psychologist McClelland (1961) who attempted to add psychological and sociological explanations for economic growth and decline. He identified entrepreneurship as one of four key forces making for economic development, along with technology, population growth, and division of labor. According to McClelland, the achievement level of a society is

\footnotetext{
${ }^{6}$ Venkataraman (1994) refers to Baumol's distinction between productive, unproductive, and destructive entrepreneurship and notes that entrepreneurs are available in every society; the supply of entrepreneurs is not a problem. What matters is the social circumstances-laws, governance structure, and incentive schemes.
}

correlated with entrepreneurial activity, and he advanced the hypothesis that "Weber's observation of the connection between Protestantism and the rise of capitalism may be a special instance of a much more general phenomenon" (McClelland 1961, p. 70).

The early stream of research that examines the characteristics of entrepreneurs has subsequently come under sharp criticism. Gartner (1985, 1988), Brockhaus (1980), Brockhaus and Nord (1979), and Brockhaus and Horwitz (1985) criticize the assumption that all entrepreneurs and their new ventures are much the same, claiming that other research suggests that the diversity among entrepreneurs may be greater than the differences between entrepreneurs and non-entrepreneurs as well as between entrepreneurial firms and nonentrepreneurial firms. Gartner also noted that many who start businesses do so only once in their lives and may subsequently not exhibit entrepreneurial behavior.

\section{Overview of the domain from the 1990s onward}

As noted by Landström et al. (2012), there were two handbooks on entrepreneurship research published prior to 1990: Kent et al. (1982) and Sexton and Smilor (1986). Not surprisingly, most of the contributors to these volumes are scholars of management; some are in sociology or engineering. Only two are economists. In recent years, several volumes have been published that provide an overview of entrepreneurship research. ${ }^{7}$ In 1990 Casson published an edited volume of previously published papers (Casson 1990) that he considered foundational for the study of entrepreneurship. The organization of the main topics covered reflects an economist's view of the boundaries of the field:

\footnotetext{
$\overline{7}$ Because of the fact that entrepreneurship as a field of research has its origins in multiple disciplines and has evolved over several decades, the handbooks on entrepreneurship that have been published provide a convenient way to organize the presentation of the material. Also, the journals specializing in entrepreneurship studies did not emerge until the last 2 or 3 decades and have had relatively little impact on the boundaries of the domain. Also, according to Teixeira (2011), of the 50 most cited studies in the entrepreneurship field, only 6 appeared in JBV, 4 in ETP, and none in SBE-the journals generally considered to be the top three journals in entrepreneurship. According to Landström et al. (2012), only one of the top 20 core works in entrepreneurship was published in one of these top three journals.
} 
1. Economic theory

Risk and uncertainty

Market process

Innovation

The entrepreneur and the firm

2. Empirical evidence on firm and industry;

New firms and market entry

Innovation and size of firm

Employment and regional growth

3. Culture and economic development

Personality and motivation

Immigrants, social mobility, and culture

Development and decline

In the early 2000s this was followed by several more edited volumes that attempted to summarize research in the field of entrepreneurship and its foundations (Westhead and Wright 2000; Shane 2002; Acs and Audretsch 2003a, b; Welsch 2004; Audretsch et al. 2011). There are many similarities in coverage. Westhead and Wright's volume contains the following topics: entrepreneurship theory, methodological issues, entrepreneurial opportunity recognition and information search, finance for entrepreneurs, entrepreneurial careers, types of entrepreneur, environments for venture creation and development, venture growth and performance, organization closure, internationalization, corporate venturing, family firms, technology-based firms, and franchising.

In 2002, Scott Shane published two edited volumes containing a broad collection of seminal and previously published works related to the study of entrepreneurship, and in 2003 Acs and Audretsch published an edited volume consisting of solicited contributions by leading contemporary scholars. The topics in these volumes turn out to be largely the same. Even though Acs and Audretsch limit their definition of entrepreneurship to businesses while Shane and Venkataraman do not, the topics covered are quite similar. The common topics are the entrepreneurial process; the existence, discovery, and exploitation of entrepreneurial opportunities; new venture formation; the social and environmental context; and new venture finance. Acs and Audretsch also include a section on entrepreneurship, economic growth, and policy (i.e., macroeconomic impact of entrepreneurial activity), while Shane and Venkataraman include more management-oriented sections on human resource assembly, organizational design, and new market creation.

The volume edited by Welsch (2004) is different from the other volumes mentioned here as it is written for educators and practitioners as well as researchers. It is also more narrowly focused on entrepreneurship as the creation of new business organizations.

A recent article by Landström et al. (2012) explores the knowledge base for entrepreneurship research using a database consisting of all references in 12 entrepreneurship handbooks published since 1982. In a bibliometric approach, the authors identify the 'knowledge producers' who have shaped the core of the entrepreneurship field and its evolution over time. It is interesting but hardly surprising that the most influential scholars are basically the same as those mentioned in the previous pages.

It could be argued that the study of entrepreneurial opportunities constitutes the core of entrepreneurship research and sets it apart from other fields. On the explorative side, entrepreneurs discover objective opportunities formed by exogenous shocks in existing markets, while on the exploitative side entrepreneurs take advantage of subjective opportunities that are created and enacted endogenously (Alvarez and Barney 2010). The former approach draws heavily on Kirzner's work, while the latter is based largely on Schumpeter.

Thus, there are two main views on the field of entrepreneurship research. One view is that the field of entrepreneurship should be concerned with the discovery of entrepreneurial opportunities, the individuals involved, and the modes of action used to exploit the opportunities (Shane and Venkataraman 2000; Low and MacMillan 1988)-the explorative side. Another view is that entrepreneurship research should focus on new enterprise and its role in furthering economic progress - the exploitation side (Acs and Audretsch 2003a, b; Acs et al. 2009). Alvarez and Barney (2010) argue that the different philosophical underpinnings of these two approaches make them incompatible, at least at the level of the firm. But at higher levels of aggregation, both involve the creation of new economic activity. The explorative side is more micro (firm) oriented, while the exploitation side looks more at aggregate outcomes. In contrast, Gartner (2001) and Welsch (2004) take the position that 
entrepreneurship is about organizing and that this has a greater likelihood of being understood through the study of firm creation.

The field seems to be in the process of being refocused, involving both broadening and narrowing down. The explorative side seems to be broadened away from the narrow focus on stable characteristics of individuals who start and run independent business firms. On the exploitation side it is increasingly being emphasized that studies of small business, family firms, internal venturing, etc., deal with entrepreneurship only if they explicitly address new ventures, i.e., discovery and exploitation of opportunities, in these different organizational contexts (Davidsson et al. 2001). These two main views reflect fairly independent (separate) lines of inquiry; within each, specific but different questions are in focus. Both approaches provide useful perspectives and make valuable contributions to the study of entrepreneurship, but there is also a need for both theory and empirical research that address both types of entrepreneurial activity and how they are related.

\section{The domain as reflected in the research of the winners of the Global Award for Entrepreneurship Research}

How well are the various parts of the entrepreneurship research domain represented by the awards that have been given thus far? It is instructive to look at the citations summarizing the contributions of the winners of the Global Award for Entrepreneurship Research since its establishment in 1996.

1996, David L. Birch: For having identified the key role of new and small firms in job creation.

1997, Arnold C. Cooper: For his pioneering work on technical entrepreneurship, new technology-based firms, and incubator organizations.

1998, David J. Storey: For the increased focus on unbiased, large-scale, and high-quality research, and for the initiation and coordination of extensive national and cross-national research programs on the central small business issues.

1999, Ian C. MacMillan: For being instrumental in introducing an international perspective involving comparative studies on cultural differences in entrepreneurship and small business behavior.
2000, Howard E. Aldrich: For integrating the most central research questions of the field, examining the formation and evolution of new and small firms with a broader sociological research context.

2001, Zoltan J. Acs and David B. Audretsch: For their research on the role of small firms in the economy, especially the role of small firms in innovation.

2002, Giacomo Becattini and Charles F. Sabel: For revitalizing Alfred Marshall's century-old ideas regarding the competitive advantages of geographical agglomerations of specialized small firms in so-called Industrial Districts.

2003, William J. Baumol: For his persistent effort to give the entrepreneur a key role in mainstream economic theory, for his theoretical and empirical studies of the nature of entrepreneurship, and for his analysis of the importance of institutions and incentives for the allocation of entrepreneurship.

2004, Paul D. Reynolds: For organizing several exemplary innovative and large-scale empirical investigations into the nature of entrepreneurship and its role in economic development.

2005, William B. Gartner: For his studies on new venture creation and entrepreneurial behavior, combining the best parts of the positivist and hermeneutical traditions.

2006, Israel M. Kirzner: For developing the economic theory emphasizing the importance of the entrepreneur for economic growth and the functioning of the capitalist process.

2007, The Diana Group (Candida G. Brush, Nancy M. Carter, Elizabeth J. Gatewood, Patricia G. Greene, and Myra M. Hart): For having investigated the supply and demand side of venture capital for women entrepreneurs. By studying women entrepreneurs who want to grow their businesses, they demonstrate the positive potential of female entrepreneurship.

2008, Bengt Johannisson: For furthering our understanding of the importance of social networks of the entrepreneur in a regional context and for his key role in the development of the European entrepreneurship and small business research tradition.

2009, Scott A. Shane: For publishing significant works that display superior conceptual acumen as well as empirical and methodological sophistication. His research covers virtually all major aspects of the entrepreneurial phenomenon: the individual(s), the 
opportunity, the organizational context, the environment, and the entrepreneurial process.

2010, Josh Lerner: For his pioneering research into venture capital (VC) and VC-backed entrepreneurship. Among his most important contributions is the synthesis of the fields of finance and entrepreneurship in the form of entrepreneurial finance. He has also made several important contributions in the area of entrepreneurial innovation, spanning the issues relating to alliances, patents, and open-source project development.

2011, Steven Klepper: For his significant contributions to our understanding of the role of new firm entry in innovation and economic growth. Klepper's work is founded on systematic longitudinal empirical analyses requiring massive, detailed data on firm entry, exit, size, location, distribution networks, and technological choices. His work integrates elements of traditional neoclassical models with evolutionary theory, bridging some of the gaps between neoclassical and evolutionary theory and between entrepreneurship research and mainstream economics.

2012, Kathleen M. Eisenhardt: For her work on 'corporate entrepreneurship'-how existing organizations can remain innovative, including through new venture creation. Eisenhardt's work links the domain of entrepreneurship research to the fields of dynamic capabilities, strategy and decision-making processes, and organization theory and design. Her original and influential contributions, both theoretical and empirical, have helped to establish entrepreneurship research more solidly in both the management and the economics literature.

2013, Maryann Feldman: For her work on the role of entrepreneurial activity in the formation of regional industry clusters. The most significant impact of Maryann Feldman's scientific output lies in research on firm location, inter-firm knowledge spillovers, and clusters/regional development. She has also addressed other aspects of contemporary entrepreneurship research, such as academic entrepreneurs and university-industry relations, intellectual property rights, and high technology entrepreneurship, especially in the pharmaceutical and biotech industries.

Figure 1 is an attempt to show graphically where each contribution fits within the domain. As seen in the figure, the domain of entrepreneurship research consists of many specific questions and contributions, and most contributions can be placed as shown. However, there are several recipients whose work is not easily represented in the figure. William Baumol's contribution is fundamental to our theoretical understanding of entrepreneurship and its role in economics, and Howard Aldrich has placed entrepreneurial activity centrally in sociology. David Story had contributed importantly to small business research by placing it in national and international research programs, and Paul Reynolds was the initiator of the systematic collection of comparable international data on entrepreneurial activity via the Global Entrepreneurship Monitor (GEM).

Given that the award is intended to recognize the cumulative (lifetime) contributions by each scholar to entrepreneurship research, the timing and sequence of the awards does not reflect the evolution of the field over time. But over the years the awarded research reveals a shift from basically quantitative and explorative approaches to more integrative and dynamic perspectives, emphasizing how entrepreneurship relates to and influences other sub-disciplines within economics, management, and sociology. It is also fair to say that the research awarded in recent years has recognized the integration of entrepreneurship research with theories in established disciplines such as economics, finance, and organization theory. ${ }^{8}$

Do these shifts towards more integrative and dynamic perspectives imply that the study of entrepreneurship is becoming established as a discipline of its own rather than as a sub-field within a variety of academic disciplines?

According to common usage, an academic discipline, or field of study, is a branch of knowledge that is taught and researched at the college or university level. Disciplines are defined (in part) and recognized by the academic journals in which research is published and the learned societies and academic departments or faculties to which their practitioners belong (Wikipedia).

Clearly entrepreneurship research covers a broad set of questions originating in a variety of academic disciplines. There seems to be no common paradigm or comprehensive theory, and the study of entrepreneurship has no natural 'home' in academia. Alvarez and Barney (2010) argue that "opportunity recognition" constitutes a core that is unique to entrepreneurship. They also distinguish between discovery and

\footnotetext{
${ }^{8}$ For further information on how integrated and dynamic perspectives are reflected in the works of recent award recipients, see Braunerhjelm and Carlsson (2011), Carlsson (2013), Eisenhardt (2013), and Klepper (2011).
} 
Fig. 1 Domain of entrepreneurship research

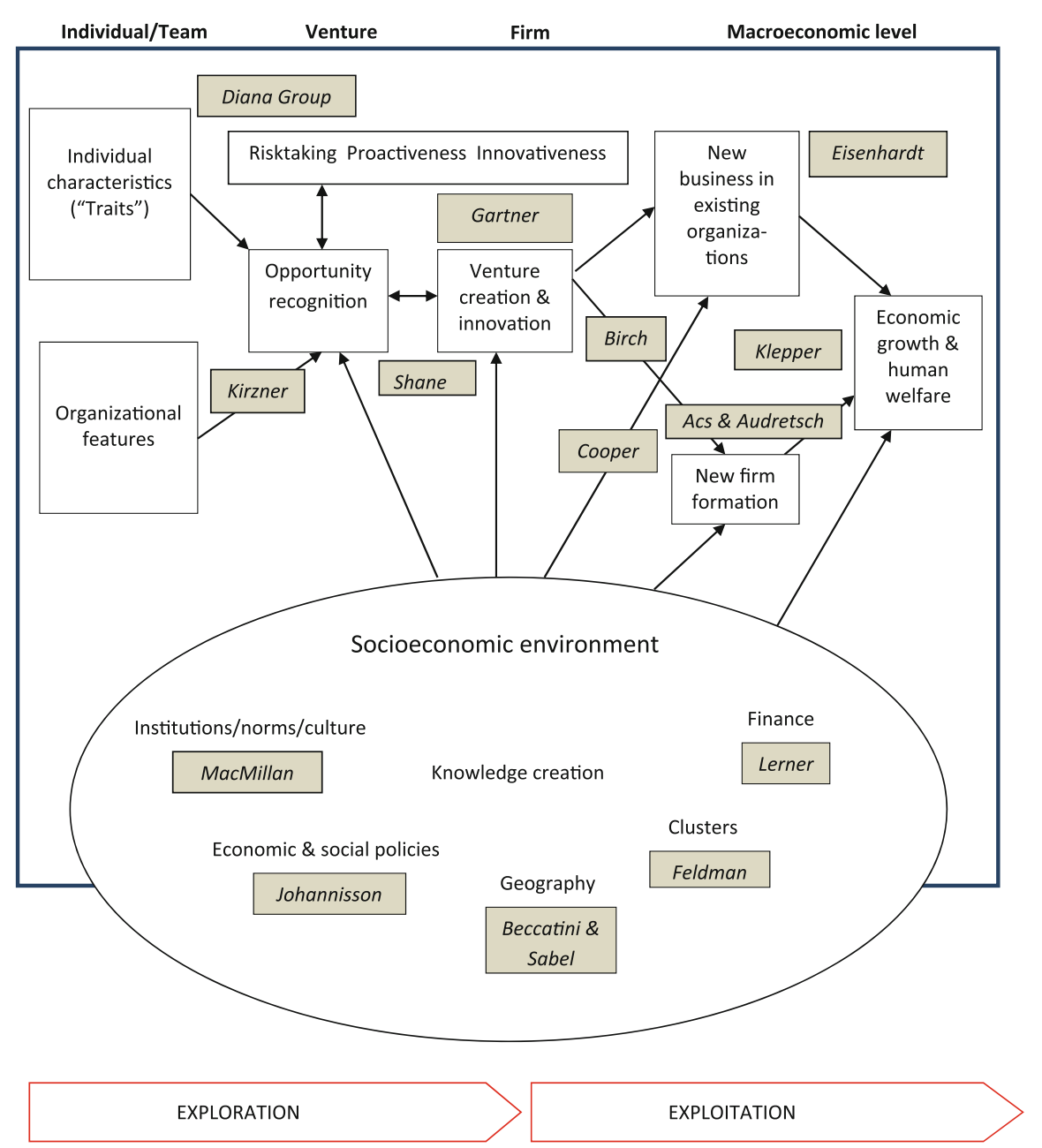

creation of opportunities as two different approaches to entrepreneurship with different philosophical underpinnings that make it difficult to integrate them into a single theory.

Aldrich (2012) takes a different approach to defining the field. He focuses on the social structure of the field rather than on its intellectual content. He argues that there are six interrelated forces that have facilitated the institutionalization of entrepreneurship research as an academic field. These forces are social networking via professional associations and conferences, publications, training and mentoring, ${ }^{9}$ funding,

\footnotetext{
9 According to Aldrich, there are now about three dozen dedicated $\mathrm{PhD}$ programs in entrepreneurship worldwide, and many $\mathrm{PhD}$ programs allow specialization in entrepreneurship as a separate track in strategy, management, or other fields.
}

status via recognition and awards, and globalization of entrepreneurship research. Aldrich argues that

[s]ince the late 1970s, the academic field of entrepreneurship research has grown from groups of isolated scholars doing research on small businesses to an international community of departments, institutes, and foundations promoting research on new and high-growth firms....[S]uch growth has produced increasingly systematic and interconnected knowledge. Growing numbers of knowledge producers and knowledge users share core concepts, principles, and research methods, and a handful of highly cited scholars have emerged as thought leaders within research subfields... [T]he field [is] increasingly formalized and anchored in a small set of intellectual bases, although there are also 
some signs of differentiation and fragmentation

(Aldrich 2012, p. 1240).

Thus, in Aldrich's view there is clearly an established community of scholars focusing on entrepreneurship research. Whether or not this portends the emergence of an academic discipline in the traditional sense is still an open question.

\section{Reflections on the continuing evolution of the research domain}

Given our definition of the domain, it appears that there are several areas in the entrepreneurship domain that are not well covered by research. One is the interaction between entrepreneurial functions at various levels and the socioeconomic environment. Historical empirical studies such as those Schumpeter called for would seem particularly useful. Moreover, the development of formal theoretical models suitable to undertake welfare analysis of the interaction between entrepreneurship and different types of institutions and policies also seems highly warranted. [See, e.g., Gans and Stern (2003), Norbäck and Persson (2009, 2011), Acs et al. (2009), and Carlsson et al. (2009) for recent work along these lines.] Future research questions of interest include, for example, what are the types of interaction between entrepreneurs and other actors and between entrepreneurial activity and institutions/norms/laws that yield fruitful outcomes? What is the role of entrepreneurial activity in the formation of innovation systems and industry clusters, and vice versa? How does entrepreneurship affect industrial development and thereby economic growth and welfare? What are the effects on the labor market and unemployment? What are the effects of labor market institutions on entrepreneurship? ${ }^{10}$

One area that is notably absent is work on social entrepreneurship - the link between entrepreneurship and human welfare. This is understandable, given that the field of social entrepreneurship did not emerge until the early 2000s. But it would seem to be a fruitful area of future research.

\footnotetext{
10 The links between entrepreneurship and economic development, particularly at the regional level, have been explored in recent research. Acs and Storey (2004) summarize the findings concerning this relationship in three special issues in Regional Studies published in 1984, 1994, and 2004.
}

Also under-represented is research relating entrepreneurship to macroeconomic outcomes. This is troubling but reflective of the theoretical difficulties of incorporating entrepreneurship into mainstream economic analysis, as noted by Baumol (1968) and Casson (1982). Another area for promising research focuses on the role of entrepreneurship in economic growth, extending the new growth theory with an emphasis on endogenous technical change (e.g., Carree and Thurik 2003; Braunerhjelm et al. 2010). This research recognizes the impact of new firm formation and firm dynamics on economic and social variables such as economic development, technological change, economic growth, productivity, wealth creation, and inequality. But there seems to be a need for a more dynamic theory in which there is room for human actors, including entrepreneurs, who are boundedly rational and who act under genuine uncertainty. Evolutionary theory offers such a framework. It would appear promising for the study of entrepreneurship; studies in this area are beginning to emerge. $^{11}$

The tension in the entrepreneurship literature between the equilibrium and the evolutionary approaches was articulated by Venkataraman (1997):

[M]ost scholars of entrepreneurship would acknowledge two fundamental premises. The first, which I call the weak premise of entrepreneurship, holds that in most societies, most markets are inefficient most of the time, thus providing opportunities for enterprising individuals to enhance wealth by exploiting these inefficiencies. The second, which I call the strong premise of entrepreneurship, holds that even if some markets approach a state of equilibrium, the human condition of enterprise, combined with the lure of profits and advancing knowledge and technology, will destroy the equilibrium sooner or later... The weak premise, although present implicitly in most works on entrepreneurship, reached its clearest articulation in the works of Kirzner (e.g., Kirzner 1979, 1985), while the strong premise is probably most familiar to people as Schumpeter's 'process of

\footnotetext{
11 See, e.g., Buenstorf (2007). For a literature survey, see Braunerhjelm (2011).
} 
creative destruction.' (Venkataraman 1997, p. 121)

An element that has been developed and can be the basis of a more systematic approach in an evolutionary theory of entrepreneurship is the recognition that individuals differ not only in their tastes but also in their access to information. The essence of entrepreneurship is "being different" because one has a different perception of the situation. Another element is recognition of the difficulties inherent in organizing a market. A third element is to relate the theory of the entrepreneur more closely to the theory of the firm. It is these functions (and not only the features or 'traits') of the entrepreneur that need to be incorporated into economic analysis. The entrepreneur is an agent of change who is concerned not merely with allocating existing resources but with generation and coordination of new resources. This cannot be done within the standard equilibrium framework; an evolutionary approach is necessary.

Finally, given the absence of a common core theory and the fragmented nature of entrepreneurship research, it is not surprising that there is a great need for methodological work. Given the desirability of developing theory, inductive, qualitative, and openended research is essential. This is true especially on the explorative side of the research domain, but moving from exploration to description, explanation and prediction is necessary throughout the whole domain. Such research is likely to require sophisticated analytical and statistical methods such as structural equation modeling and advanced econometrics. In particular, applied work based on more careful design as well as on theoretical models yielding more credible and robust estimates seems highly warranted. Kathleen Eisenhardt's work on corporate entrepreneurship, founded on her study on "Building Theories from Case Study Research" (Eisenhardt 1989), is an excellent example. On the exploitation side of the domain there is a need for high quality data and analysis, including carefully done large-scale surveys. The work of Steven Klepper, founded on systematic longitudinal empirical analyses requiring massive, detailed, and painstaking collection and analyses of historical data on firm entry, exit, size, location, distribution networks, and technological choices, is a good example here. The systematic gathering of longitudinal internationally comparable data on multiple levels, such as that by the Global Entrepreneurship Monitor (GEM), should open up new avenues of research.

The purpose of the Global Award for Entrepreneurship Research is to promote and reward scholarship that has made "a significant contribution to theorybuilding concerning entrepreneurship and small business development, the role and importance of new firm formation and the role of SMEs in economic development." Several of the early awards were given for research on small business development. As mentioned above, it was only in the late 1990s that a clear distinction began to be made between small business economics and entrepreneurship research. The emphasis in the awarded research has shifted gradually from the explorative side (individual/team features and venture creation) toward the exploitation side (new business formation in both new and existing firms, and its outcome in the form of economic growth). A few contributions linking entrepreneurship and the socioeconomic environment have also been awarded. The most recent awards have been given to scholarship that integrates the analysis of entrepreneurial activities with mainstream research in various disciplines such as finance, industrial organization, strategic management, and organization theory. These are important contributions that link entrepreneurship to established disciplines and that also enrich these disciplines. But our review of the entrepreneurship literature (including that of the award winners) shows that there is not much referencing of literature on entrepreneurship outside each author's own discipline. The lack of crossreferencing to other disciplines is not confined to the entrepreneurship field, however. It is even more evident when considering the literature on such closely related fields as innovation and science and technology studies (Bhupatiraju et al. 2012).

We believe that entrepreneurship research could further develop into a set of core insights of the domain and that this development could involve integrating the insights from various disciplines. The domain of entrepreneurship research has evolved over time, and many authors have made interesting contributions to a set of questions at the individual, firm, and macro levels. There are signs of convergence on some core issues, particularly creation and discovery of opportunities, but there are also signs of continuing specialization and fragmentation. Certainly 
entrepreneurship has emerged as a legitimate field of study within universities, and there is a large and growing international community of entrepreneurship scholars. We are convinced that future developments will further enrich our understanding and address new sets of problems and phenomena.

Open Access This article is distributed under the terms of the Creative Commons Attribution License which permits any use, distribution, and reproduction in any medium, provided the original author(s) and the source are credited.

\section{References}

Acs, Z. J., \& Audretsch, D. B. (2003a). Handbook of entrepreneurship research: An interdisciplinary survey and introduction. Boston: Kluwer Academic Publishers.

Acs, Z. J., \& Audretsch, D. B. (2003b). Introduction to the handbook of entrepreneurship research. In Z. J. Acs \& D. B. Audretsch (Eds.), Handbook of entrepreneurship research: An interdisciplinary survey and introduction (pp. 3-20). Boston: Kluwer Academic Publishers.

Acs, Z. J., Braunerhjelm, P., Audretsch, D. B., \& Carlsson, B. (2009). The knowledge spillover theory of entrepreneurship. Small Business Economics, 32(1), 15-30.

Acs, Z. J., \& Storey, D. J. (2004). Introduction: Entrepreneurship and economic development. Regional Studies, 38(8), 871-877.

Aldrich, H. E. (2012). The emergence of entrepreneurship as an academic field: A personal essay on institutional entrepreneurship. Research Policy, 41(7), 1240-1248.

Alvarez, S. A., \& Barney, J. B. (2010). Entrepreneurship and epistemology: The philosophical underpinnings of the study of entrepreneurial opportunities. The Academy of Management Annals, 4(1), 557-583.

Audretsch, D. B., Falck, O., Heblich, S., \& Lederer, A. (Eds.). (2011). Handbook of research on innovation and entrepreneurship. Cheltenham: Elgar.

Barth, F. (1963). The role of the entrepreneur of social changes in northern Norway. Oslo: Universitetsforlaget.

Baumol, W. J. (1968). Entrepreneurship in economic theory. American Economic Review, Papers and Proceedings, 58(2), 64-71.

Baumol, W. J. (1990). Entrepreneurship, productive, unproductive and destructive. Journal of Political Economy, 98(5), 893-921.

Bhupatiraju, S., Nomaler, Ö., Triulzi, G., \& Verspagen, B. (2012). Knowledge flows-analyzing the core literature of innovation, entrepreneurship and science and technology studies. Research Policy, 41(7), 1205-1218.

Braunerhjelm, P. (2011). Entrepreneurship, innovation and economic growth. Interdependencies, irregularities and regularities. In D. Audretsch, O. Falck, P. Heilbach, \& A. Lederer (Eds.), Handbook of innovation and entrepreneurship (pp. 161-213). Cheltenham: Edward Elgar.

Braunerhjelm, P., Acs, Z. J., Audretsch, D. B., \& Carlsson, B. (2010). The missing link: Knowledge diffusion and entrepreneurship in endogenous growth. Small Business Economics, 34(2), 105-125.

Braunerhjelm, P., \& Carlsson, B. (2011). Steven Klepper: Recipient of the 2011 Global Award for Entrepreneurship Research. Small Business Economics, 37(2), 131-140.

Braunerhjelm, P., \& Henrekson, M. (2009). Awarding entrepreneurship research: A presentation of the global award. Entrepreneurship Theory and Practice, 33(3), 809-814.

Brockhaus, R. H. (1980). Risk taking propensity of entrepreneurs. Academy of Management Journal, 23(3), 509-520.

Brockhaus, R. H., \& Horwitz, P. S. (1985). The psychology of the entrepreneur. In D. L. Sexton \& R. W. Smilor (Eds.), The art and science of entrepreneurship. Cambridge, MA: Ballinger.

Brockhaus, R. H., \& Nord, W. R. (1979). An exploration of factors affecting the entrepreneurial decision: Personal characteristics vs. environmental conditions. In Proceedings of the annual meeting of the academy of management.

Buenstorf, G. (2007). Creation and pursuit of entrepreneurial opportunities: An evolutionary economics perspective. Small Business Economics, 28, 323-337.

Cantillon, R. (1755). Essay on the Nature of Trade inGeneral. London: Henry Higgs (edition and translation 1959).

Carlsson, B. (1989a). The evolution of manufacturing technology and its impact on industrial structure: An international study. Small Business Economics, 1(1), 21-37.

Carlsson, B. (1989b). Flexibility and the theory of the firm. International Journal of Industrial Organization, 7(2), 179-203.

Carlsson, B. (1992). The rise of small business: Causes and consequences. In W. J. Adams (Ed.), Singular Europe: Economy and polity of the European community after 1992 (pp. 145-169). Ann Arbor, MI: University of Michigan Press.

Carlsson, B. (2013). Kathleen Eisenhardt: Recipient of the 2012 Global Award for Entrepreneurship Research. Small Business Economics, 40(4), 797-804.

Carlsson, B., Acs, Z. J., Audretsch, D. B., \& Braunerhjelm, P. (2009). Knowledge creation, entrepreneurship, and economic growth: A historical review. Industrial and Corporate Change, 18(6), 1193-1229.

Carree, M. A., \& Thurik, A. R. (2003). The impact of entrepreneurship on economic growth. In Z. J. Acs \& D. B. Audretsch (Eds.), Handbook of entrepreneurship research: An interdisciplinary survey and introduction (pp. 437-471). Boston: Kluwer Academic Publishers.

Casson, M. (1982). The entrepreneur: An economic theory. Totowa, NJ: Barnes \& Noble Books.

Casson, M. (Ed.). (1990). Entrepreneurship. Cheltenham: Elgar.

Chandler, Alfred. D., Jr. (1962). Strategy and structure: Chapters in the history of the industrial enterprise. Boston: The MIT Press.

Chandler, Alfred. D., Jr. (1977). The visible hand: The managerial revolution in American business. Cambridge: Harvard University Press.

Chandler, Alfred. D., Jr. (1990). Scale and scope: The dynamics of industrial capitalism. Cambridge: Harvard University Press.

Cole, A. H. (1944). A report on research in economic history. The Journal of Economic History, 4(1), 49-72. 
Cole, A. H. (1970). The committee on research in economic history: An historical sketch. The Journal of Economic History, 30(4), 723-741.

Cooper, A. (2003). Entrepreneurship: The past, the present, the future. In Z. J. Acs \& D. B. Audretsch (Eds.), Handbook of entrepreneurship research: An interdisciplinary survey and introduction (pp. 21-34). Boston: Kluwer Academic Publishers.

Cornelius, B., Landström, H., \& Persson, O. (2006). Entrepreneurial studies: The dynamic research front of a developing social science. Entrepreneurship Theory and Practice, 30(3), 375-398.

Courvisanos, J., \& Mackenzie, S. (2011). Role of history in economic theory: Critical realism and Joseph Schumpeter's Plea for entrepreneurial history. In Paper presented at the 2011 history of economic thought society of Australia conference. http://www.hetsa.org.au/hetsa2011/abstracts_ index.html.

Dahmén, E. (1950). Svensk industriell företagarverksamhet; kausalanalys av den industriella utvecklingen 1919-1939. (Entrepreneurial activity in Swedish industry in the period 1919-1939), Stockholm: Industriens Utredningsinstitut, with an English summary.

Davidsson, P., Low, M. B., \& Wright, M. (2001). Editor's introduction: Low and MacMillan ten years on: Achievements and future directions for entrepreneurship research. Entrepreneurship Theory and Practice, 25(4), Summer, 5-15.

Eisenhardt, K. (1989). Building theories from case study research. Academy of Management Review, 14(4), 532-550.

Eisenhardt, K. M. (2013). Top management teams and the performance of entrepreneurial firms. Small Business Economics, 40(4), 805-816.

Gans, J., \& Stern, S. (2003). The product market and the market for ideas: Commercialization strategies for technology entrepreneurs. Research Policy, 32(2), 333-350.

Gartner, W. B. (1985). A conceptual framework for describing the phenomenon of new venture creation. Academy of Management Review, 10(4), 696-706.

Gartner, W. B. (1988). 'Who Is an Entrepreneur?' Is the wrong question. American Journal of Small Business, Spring 1988, 11-32.

Gartner, W. B. (1990). What are we talking about when we talk about entrepreneurship? Journal of Business Venturing, 5, 15-28.

Gartner, W. B. (2001). Is there an elephant in entrepreneurship? Blind assumptions in theory development. Entrepreneurship Theory and Practice, 25(4), 27-37.

Gartner, W. B., \& Shane, S. A. (1995). Measuring entrepreneurship over time. Journal of Business Venturing, 10, 283-301.

Geertz, C. (1963). Peddlers and princes. Chicago: Chicago University Press.

Hayek, F. A. (1945). The use of knowledge in society. American Economic Review, 35(4), 519-530.

Hébert, R. F., \& Link, A. N. (1989). In search of the meaning of entrepreneurship. Small Business Economics, 1(1), 39-49.

Heider, F. (1958). The psychology of interpersonal relations. New York: Wiley.

Henrekson, M., \& Lundström, A. (2009). The Global Award for Entrepreneurship Research. Small Business Economics, 32, $1-14$.
Henrekson, M., \& Stenkula, M. (2007). Entreprenörskap. Stockholm: SNS Förlag.

Hughes, Jonathan. R. T. (1983). Arthur cole and entrepreneurial history. Business and Economic History, 12, 139-144.

Kent, C. A., Sexton, D. L., \& Vesper, K. H. (Eds.). (1982). Encyclopedia of entrepreneurship. Englewood Cliffs, NJ: Prentice-Hall.

Kihlstrom, R. E., \& Laffont, J.-J. (1979). A general equilibrium entrepreneurial theory of firm formation based on risk aversion. Journal of Political Economy, 87(4), 719-748.

Kirzner, I. (1973). Competition and entrepreneurship. Chicago: University of Chicago Press.

Kirzner, I. (1979). Perception, opportunity and profit. Chicago: University of Chicago Press.

Kirzner, I. (1985). Discovery and the capitalist process. Chicago: University of Chicago Press.

Klein, B. (1977). Dynamic economics. Boston: Harvard University Press.

Klepper, S. (2011). Nano-economics, spinoffs, and the wealth of regions. Small Business Economics, 37(2), 141-154.

Knight, F. H. (1921). Risk, uncertainty and profit. New York: Houghton Mifflin Company.

Landström, H. (1999). The roots of entrepreneurship research. The intellectual development of a research field. New England Journal of Entrepreneurship, 1(2), 9-20.

Landström, H. (2000). Entreprenörskapets rötter [The Roots of Entrepreneurship]. Lund: Studentlitteratur.

Landström, H. (2005). Pioneers in entrepreneurship and small business research. New York: Springer.

Landström, H., Harirchi, G., \& Åström, F. (2012). Entrepreneurship: Exploring the knowledge base. Research Policy, 41(7), 1154-1181.

Leibenstein, H. (1968). Entrepreneurship and development. American Economic Review, 58(2), 72-83.

Lipset, S. M. (1967). Values, education, and entrepreneurship. In S. M. Lipset \& A. Solari (Eds.), Elites in Latin America. London: Oxford University Press.

Low, M., \& MacMillan, I. (1988). Entrepreneurship: Past research and future challenges. Journal of Management, 35, 139-161.

McClelland, D. C. (1961). The achieving society. Princeton: D. Van Nostrand Company, Inc.

Mises, L. (1949). Human action: A treatise on economics. San Francisco, CA: Laissez Faire.

Murphy, P. J., Liao, J., \& Welsch, H. P. (2006). A conceptual history of entrepreneurial thought. Journal of Management History, 12(1), 12-35.

Nelson, R. R., \& Winter, S. G. (1982). An evolutionary theory of economic growth. Cambridge, MA: Harvard University Press.

Norbäck, P.-J., \& Persson, L. (2009). The organization of the innovation industry: Entrepreneurs, venture capitalist and established firms. The Journal of the European Economic Association, 6, 1261-1290.

Norbäck, P.-J., \& Persson, L. (2011). Entrepreneurial innovations, competition and competition policy. European Economic Review, 56(3), 488-506.

OECD. (1998). Fostering entrepreneurship. Paris: OECD.

Say, J. B. (1803). A treatise on political economy: Or, the production, distribution and consumption of wealth. New York: Augustus M. Kelley, 1964. 
Schumpeter, J. A. (1934). The theory of economic development. Cambridge, MA: Harvard Economic Studies.

Schumpeter, J. A. (1942). Capitalism, socialism, and democracy. New York: Harper \& Row.

Sexton, D. L., \& Smilor, R. W. (1986). The art and science of entrepreneurship. Cambridge, MA: Ballinger.

Shane, S. (2002). The foundations of entrepreneurship (Vol. I \& II). Cheltenham: Edward Elgar.

Shane, S., \& Venkataraman, S. (2000). The promise of entrepreneurship as a field of research. Academy of Management Review, 25(21), 217-226.

Shaver, K. G. (2003). The social psychology of entrepreneurial behaviour. In Z. J. Acs \& D. B. Audretsch (Eds.), Handbook of entrepreneurship research: An interdisciplinary survey and introduction. Boston: Kluwer Academic Publishers.

Stevenson, Howard. H. (2004). Intellectual foundations of entrepreneurship. In H. P. Welsch (Ed.), Entrepreneurship: The way ahead. New York: Routledge.

Teixeira, Aurora. A. C. (2011). Mapping the (in)visible college(s) in the field of entrepreneurship. Scientometrics, 89, $1-36$.
Venkataraman, S. (1994). Associate editor's note. Journal of Business Venturing, 9(1), 3-6.

Venkataraman, S. (1997). The distinctive domain of entrepreneurship research. In J. Katz \& R. Brockhaus (Eds.), Advances in entrepreneurship, firm emergence and growth (Vol. 3, pp. 119-138). Greenwich, CT: JAI Press.

Vesper, K. (1982). Introduction and summary of entrepreneurial research. In Kent, Sexton \& Vesper (Eds.), Encyclopedia of entrepreneurship (pp. xxxi-xxxviii). Englewood Cliffs, NJ: Prentice-Hall.

Welsch, H. P. (Ed.). (2004). Entrepreneurship: The way ahead. New York: Routledge.

Wennekers, S., \& Thurik, R. (1999). Linking entrepreneurship and economic growth. Small Business Economics, 13(1), 27-55.

Wennekers, S., \& Thurik, R. (2001). Institutions, entrepreneurship and economic performance. Working paper. Rotterdam: Erasmus University.

Westhead, P., \& Wright, M. (Eds.). (2000). Advances in entrepreneurship (Vol. I). Cheltenham, UK: Elgar. 